\title{
28 Research Suare \\ Selection for Yield Over Five Decades Favored an Isohydric and Phenological Adaptations to Early- Season Drought in Australian Wheat
}

Jairo A. Palta ( $\sim$ jairo.palta@csiro.au )

The University of Western Australia https://orcid.org/0000-0002-4116-7670

Faisal Khan

Yupeng Feng

Yinglong Chen

Victor 0 Sadras

Kadambot H.M. Siddique

\section{Research Article}

Keywords: Breeding, Early-season drought, Phenotype, Photosynthesis, Stomata

Posted Date: January 28th, 2022

DOI: https://doi.org/10.21203/rs.3.rs-1283868/v1

License: @ (i) This work is licensed under a Creative Commons Attribution 4.0 International License.

Read Full License 


\section{Abstract}

Background and Aims:

Climate change in the Mediterranean-climate region of Australia is reducing growing season rainfall and delaying first autumn rain or the onset of 'autumn break'. We tested the hypothesis that selection for yield and agronomic adaptation has favored traits for early season drought a in Australian wheat (Triticum aestivum L.).

Methods

Ten wheat varieties released between 1958 and 2012 were grown in $1.0 \mathrm{~m}$ deep columns in a glasshouse. After sowing in dry soil, the equivalent of $25 \mathrm{~mm}$ rainfall was supplied, with no subsequent watering provided for 32 days to induce early season drought. We measured soil and plant water status, gas exchange, shoot and root traits at the end of drought (32 days after sowing) and at anthesis, and grain yield at maturity.

Results

Grain yield increased with year of release at $0.43 \% \mathrm{yr}^{-1}$ under well-watered conditions and at $0.35 \% \mathrm{yr}^{-1}$ under drought. The improved yield under drought was associated with a shorter time to flowering, and a shift from isohydric behavior in older varieties (i.e., reduced stomatal conductance in response to drought) to anisohydric behavior in newer varieties that reduced leaf area and maintained higher stomatal conductance and higher photosynthesis per unit leaf area.

Conclusions

Direct selection for yield and agronomic adaptation between 1958 and 2012 has improved adaptation to early-season drought. Our collection of varieties is an interesting model to probe for variation in drought tolerance.

\section{Introduction}

Wheat will remain critical for food security in the foreseeable future, but drought limits its production in major mega-environments worldwide (Shiferaw et al., 2013; Fischer et al., 2014). Adaptive traits need to be tailored to the specific timing, intensity, and duration of water stress (Jordan \& Miller, 1980; Tardieu, 2012), hence the importance of probabilistic, spatial quantification of drought patterns (Chenu, 2015). Modeling the seasonal dynamics of water supply and demand using historic climate series and climate projections $(2030,2070)$ returned four types of drought for wheat in Australia (Chenu et al., 2013; Watson et al., 2017) linked toa non-stress condition, extreme drought with an onset at $500^{\circ} \mathrm{Cd}$ before flowering, and increasing stress as the season progresses. However, modeling water supply and demand is unreliable for small canopies early in the season, precluding the quantification of early-season drought (K. Chenu, personal communication, March 2021). 
Climate change in the Mediterranean-climate region of Australia is increasing maximum temperature, reducing minimum temperature and growing season rainfall, and delaying first autumn rain or the onset of 'autumn break' (Pook et al., 2009; Hochman et al., 2017; Cann et al., 2020). In response to the delayed in autumn break, many Australian wheat growers are sowing their entire cropping land before the autumn break, further increasing the risk of early season drought (Fletcher et al., 2015, 2016). In Western Australia, wheat crops sown into dry soil germinate and emerge after the first 20-25 mm rainfall, potentially leaving crops vulnerable to 20-23 days drought after emergence in two of four years and 3032 days drought in one of four years (Chapman and Asseng 2001). While seedlings can survive early season drought, their growth and development are slow, reducing root and shoot biomass at anthesis and grain yield (Armstrong et al., 1996; French and Palta, 2014).

Comparisons of varieties in historic collections reveal changes in the crop phenotype associated with selective pressure for yield and agronomic adaptation (Austin et al., 1980; Slafer, 1994; Roche, 2015). A collection of wheat varieties adapted to winter-rainfall in Australia showed that five decades of breeding favored (i) a communal phenotype with reduced competitive ability (Sadras and Lawson, 2011, Cossani and Sadras, 2021), (ii) higher crop photosynthesis associated with more erect canopies that favor light penetration, higher nitrogen uptake and greener leaves (Sadras et al., 2012a, Cossani and Sadras, 2021), (iii) higher nitrogen-water co-limitation (Sadras and Lawson, 2013; Cossani and Sadras, 2019), and (iv) a smaller root system with enhanced nitrogen uptake per unit root length (Aziz et al., 2017). In contrast to the adaptive role of a smaller root system (Aziz et al., 2017), a comparison of three varieties with exceptionally large and small root systems showed that larger root systems associated with late flowering adapted to severe early season drought allowing greater recovery in leaf area and shoot and root biomass by anthesis (Figueroa Bustos et al., 2019).

Here, we used our historical collection of Australian wheats to test the hypothesis that selection for yield and agronomic adaptation in winter-rainfall environments has improved yield under early season drought. We measured phenological and physiological traits to identify shifts associated with the putative improvement in drought tolerance.

\section{Materials And Methods}

\section{Plant material and growth conditions}

We used ten Australian wheat (Triticum aestivum L.) varieties released between 1958 and 2012 and previously phenotyped in field and glasshouse conditions (Aziz et al., 2017, Sadras and Lawson, 2011, Sadras et al., 2012a, Sadras and Lawson, 2013; Cossani and Sadras, 2019, 2021). Heron (released in 1958), Halberd (1969), Condor (1973), Spear (1984), Janz (1989), Frame (1994), Krichauff (1997), Wyalkatchem (2001), Gladius (2007), and Mace (2012). These varieties were selected using two criteria: wide adoption in the winter-rainfall environments of Australia and narrow phenological range. Plants were grown in an evaporatively-cooled glasshouse at The University of Western Australia, Perth, Australia $\left(31^{\circ} 93^{\prime} \mathrm{S}, 115^{\circ} 83^{\prime} \mathrm{E}\right)$ from May to November 2018 , with an average air temperature of $17^{\circ} \mathrm{C}$ (range 7- 
$26^{\circ} \mathrm{C}$ ), relative humidity of $67 \%$, natural photoperiod from $10.5-13.0 \mathrm{~h}$, and average photosynthetic photon flux density of $935 \pm 19 \mu \mathrm{mol} \mathrm{m}^{-2} \mathrm{~s}^{-1}$ measured at the plant level at 13:00 $\mathrm{h}$.

Plants were grown in $1.0 \mathrm{~m}$ deep PVC columns ( $0.15 \mathrm{~m}$ diameter) filled with soil, with $4 \mathrm{~cm}$ of gravel at the bottom to facilitate drainage. The soil was a reddish-brown sandy clay loam, Red Calcic Dermosal (Isbell, 1993), collected from the top $0-15 \mathrm{~cm}$ of soil in a field at Cunderdin ( $\left.31^{\circ} 64^{\prime} \mathrm{S}, 17^{\circ} 24^{\prime} \mathrm{E}\right)$, Western Australia. It comprised $63.5 \%$ brown sand, $8.3 \%$ silt and $28.3 \%$ clay with $\mathrm{pH}, 6.0$ measured in a $1: 5$ suspension of soil in $0.01 \mathrm{M} \mathrm{CaCl}_{2}$. The soil contained $6 \mu \mathrm{g} \mathrm{g}^{-1}$ nitrate- $\mathrm{N}, 4 \mu \mathrm{g} \mathrm{g}^{-1}$ ammonium- $\mathrm{N}, 46 \mu \mathrm{g}$ $\mathrm{g}^{-1}$ Colwell $\mathrm{P}$, and $691 \mathrm{\mu g} \mathrm{g}^{-1}$ Colwell $\mathrm{K}$. Air-dried soil was sieved to $2 \mathrm{~mm}$ and mixed with coarse yellow sand (200-2000 $\mu \mathrm{m}$ particle size) in a 4:1 ratio using a cement mixer for uniformity. The soil was packed slowly into the in $0.2 \mathrm{~m}$ sections from the top to a bulk density of approximately $1.50 \mathrm{~g} \mathrm{~cm}^{-3}$. At sowing, the equivalent of $60 \mathrm{~kg} \mathrm{~N} \mathrm{ha}^{-1}$ as urea; $72 \mathrm{~kg} \mathrm{Pha}^{-1}$ as amended superphosphate (with $\mathrm{Cu}, \mathrm{Zn}, \mathrm{Mo}, \mathrm{S}$ ), and $70 \mathrm{~kg} \mathrm{~K} \mathrm{ha}^{-1}$ as potash was mixed into the top $0.1 \mathrm{~m}$ of soil in each column. These rates are recommended for wheat on Cunderdin soil (Flower et al., 2012). Four uniform seeds were sown along a center row in each column and thinned to two per column at the two-leaf stage, corresponding to a field sowing density of 113 plants $\mathrm{m}^{-2}$ (Lemerle et al., 2004).

\section{Treatments}

We established a factorial experiment combining the 10 varieties and two watering regimes [ well-watered (WW) and early season drought (ESD)] in a completely randomized block design with four replicates. The columns were rotated weekly to minimize spatial variability.

Forty-eight hours before sowing, the well-watered columns were slowly watered by hand to saturation, and the soil surface was covered with aluminum foil to prevent evaporation. From sowing to 32 days after sowing (DAS), the well-watered treatment received $200 \mathrm{~mL}$ water per week to maintain the soil water content to $90 \%$ field capacity. The columns of the drought treatment were maintained dry until sowing. Immediately after sowing, the ESD columns were watered with the equivalent of $25 \mathrm{~mm}$ rainfall $(\sim 441 \mathrm{~mL}$ water), which wet the top $0.12-0.15 \mathrm{~m}$ soil to a volumetric water content $\sim 20 \%$; no further water was applied for 32 days. After this time and until physiological maturity (Z91) (Zadoks et al., 1974), both the well-watered and droughted plants were equally watered by hand twice per week to maintain the soil water content close to $90 \%$ field capacity and to avoid drainage of excess water.

\section{Phenology, soil water content, leaf water potential, stomatal conductance and leaf photosynthesis}

Phenological development was monitored regularly using Zadok's scale (Zadoks et al. 1974). At 32 DAS, before terminating the drought treatment, we measured volumetric soil water content, leaf water potential $\left(\Psi_{\text {leaf }}\right)$, stomatal conductance $\left(g_{\mathrm{s}}\right)$, and leaf net photosynthesis rate. Volumetric soil water content in the top $0.15 \mathrm{~m}$ of the soil profile was measured with a $15 \mathrm{~cm}$ soil moisture probe connected to a water content sensor (CS658 HydroSense II Water Content Sensor, Campbell Scientific, Australia).

Measurements of $\Psi_{\text {leaf }} g_{\mathrm{s}}$, and leaf net photosynthesis rate were made on the last expanded leaf of the 
main stem on four replicate columns (two plants), between 10:30 and 14:00 on a day with clear sky. Rates of leaf net photosynthesis and $g_{\mathrm{s}}$ were measured with a LI-COR gas-exchange system (LI-6400, LICOR Bioscience, Nebraska, USA) with an LED light source on the leaf chamber. The cuvette $\mathrm{CO}_{2}$ concentration was set to $380 \mu \mathrm{mol}^{-1}$ and LED light intensity to $900 \mu \mathrm{mol} \mathrm{m}^{-2} \mathrm{~s}^{-1}$, the average saturation intensity for photosynthesis in wheat (Austin 1990). Immediately after these measurements, $\Psi_{\text {leaf }}$ was measured using a Scholander pressure chamber (model 1000, PMS Instrument Co., Oregon, USA). The last expanded leaf of the main stem was loosely covered with a plastic sheath before excision and during the measurement to avoid evaporation (Turner 1988).

\section{Shoot traits}

We measured leaf area, leaf biomass, specific leaf area (SLA), tiller number, and shoot biomass twice at 32 DAS, before terminating the drought treatment, and at anthesis (Z61) for each variety. At each sampling, four columns per variety and treatment were harvested and each column (two plants) served as a replicate. Shoots were cut at the crown and leaf area was measured using a portable leaf area meter (LI-3000, Li-COR Biosciences, Lincoln, NE, USA). The number of tillers was recorded, and stems and leaves were dried in an oven at $70^{\circ} \mathrm{C}$ for $48 \mathrm{~h}$ and then weighed to determine dry weights. Shoot biomass, grain yield and yield components were measured at maturity. Spikes per plant were counted before separated from shoots, oven-dried at $60^{\circ} \mathrm{C}$ for $48 \mathrm{~h}$, and then threshed by hand. The number and weight of grains per plant were recorded. Harvest index $(\mathrm{HI})$ was calculated as the ratio of grain yield to total shoot biomass.

\section{Root traits}

We measured total root length, total root biomass, total root length density (root length per unit of soil volume; RLD), and specific root length (SRL, root length per unit of biomass), which is an indirect measure of root thickness. Measurements were made at 32 DAS, just before terminating the drought treatment, and at anthesis (Z61) for each variety. Immediately after harvesting the shoots, the soil profile in each column was sampled from top to bottom. The roots in each column were recovered from the soil by washing and repeated sieving through a $1.4 \mathrm{~mm}$ sieve to produce a clean sample as described by Palta and Fillery (1993). After the roots were recovered from a section of the soil profile, they were placed in plastic bags and stored at $4^{\circ} \mathrm{C}$ until measurement, often two days later. The root length in each root sample was measured as described by Liao et al. (2004). Briefly, roots were stained for 30 min with $0.1 \%$ $(\mathrm{w} / \mathrm{v})$ methyl blue prior to analysis, placed in a $0.2 \cdot 0.3 \mathrm{~m}$ glass tray in about $3 \mathrm{~mm}$ water, and untangled to avoid any overlap. The glass tray was placed on the scanner, and the roots were scanned at 600 pixels per mm using an Epson scanner (ES2200) connected to a computer. The root material was then dried at $70^{\circ} \mathrm{C}$ for $48 \mathrm{~h}$ and weighed. The images were analyzed for root length using WinRHIZO 2009 (model Pro, second version, Regent Instruments, Québec, Canada). Total root length density was calculated as the total root length to $1.0 \mathrm{~m}$ of the soil profile divided by the soil volume in column $\left(0.0176 \mathrm{~m}^{3}\right)$.

\section{Statistical analysis}


The data were analyzed using SPSS 21.0 Statistical Analysis System, Origin Lab 10.0 and Microsoft Excel 2013. Two-way ANOVAs were performed with year of release and watering regimeas main effects to compare shoot biomass and root system traits. Multiple comparisons were done using the least significant difference (LSD) test. The results with significant interactions were interpreted based on the LSD, and the main effects were not considered. Chronological trends of phenotypic traits were tested using least-square regressions of trait deviation vs year of release. Absolute ( $\mathrm{g} \mathrm{plant}^{-1} \mathrm{yr}^{-1}$ ) and relative $\left(\% \mathrm{yr}^{-1}\right)$ rates of change for each trait were calculated as the slope of the least-square regression between the trait and year of release. The relative rate was calculated in relation to the newest variety (Fischer et al., 2014). We report $p$-value as a continuous quantity (Greenland, 2019).

We calculated the drought susceptibility index (DSI) (Fisher and Maurer, 1978) as follows:

$\mathrm{DSI}=\left[1-\left(\mathrm{Y}_{\mathrm{d}} / \mathrm{Y}_{\mathrm{w}}\right)\right] / \mathrm{D}$ Equation $(1)$

where $Y$ is yield, ${ }_{d}$ and ${ }_{w}$ are drought and well-watered respectively, and D is drought intensity $=1$ - (mean $Y_{d}$ of all varieties/(mean $Y_{w}$ of all varieties).

\section{Results}

Soil water content, leaf water potential, stomatal conductance and leaf gas-exchange at the end of the drought period

Figure 1 and Table 1 summarize soil water content and water-related traits at $32 \mathrm{DAS}$, just before terminating the drought treatment. Under well-watered conditions, topsoil $(0-0.15 \mathrm{~m})$ volumetric water content was high (14.5-16.2\%) and did not vary with year of release of the varieties (Fig. 1a). Consistently, leaf water potential $\left(\Psi_{\text {leaf }}\right)$, stomatal conductance $\left(g_{\mathrm{s}}\right)$, leaf photosynthetic rate and leaf transpiration rate were maintained high and did not vary with year of release under well-watered conditions (Fig. 1b-e, Table 1).

Under drought, the volumetric soil water content ranged from 7.6-9.0\% and decreased with year of release. Newer varieties dried the soil more than their older counterparts (Fig. 1a; Table 1). $\Psi_{\text {leaf }}$ decreased linearly with the year of release from -1.29 to $-1.80 \mathrm{MPa}$ at a rate of $-0.008 \pm 0.002 \mathrm{MPa} \mathrm{yr}^{-1}$ (Fig. $1 \mathrm{~b}$, Table 1). Stomatal conductance, leaf photosynthetic rate, and leaf transpiration rate increased linearly with year of release (Fig. 1c,d; Table 1).

\section{Leaf area, tiller number, and shoot biomass at the end of the drought period}

Under well-watered conditions, leaf area ranged from 76.0-110 $\mathrm{cm}^{2}$ plant $^{-1}$ and did not vary with year of release (Fig. 1f, Table 1). Under drought, leaf area decreased linearly with the year of release from 63.2 to $30.6 \mathrm{~cm}^{2}$ plant $^{-1}$ at a rate of $0.58 \pm 0.11 \mathrm{~cm}^{2}$ plant $^{-1} \mathrm{yr}^{-1}$ (Fig. 1f; Table 1). Tiller number decreased 
linearly with year of release from 2.8 to 1.0 tillers plant $^{-1}$ in well-watered plants and 1.12 to 0.30 tillers plant $^{-1}$ under drought (Fig. 1g, Table 1). The rate of decline in tiller number with year of release was 2.8fold higher under well-watered conditions than under drought (Fig. 1g, Table 1). Under well-watered conditions, shoot biomass decreased with year of release from 0.34 to $0.20 \mathrm{~g} \mathrm{plant}^{-1}$ at a rate of $0.002 \pm$ $0.0006 \mathrm{~g} \mathrm{plant}^{-1} \mathrm{yr}^{-1}$ (Fig. 1h; Table 1). Under drought, shoot biomass ranged from 0.15 and $0.20 \mathrm{~g}$ plant $^{-1}$, and did not vary with year of release (Fig. 1h, Table 1).

\section{Root traits at the end of the drought period}

Figure 2 and Table 1 summarize the variation in root traits under the two watering regimes at the end of the drought treatment. Total root length decreased linearly with year of release under well-watered and drought conditions (Fig. 2a, Table 1). Under well-watered conditions, total root length decreased from 9.8 $\mathrm{m} \mathrm{plant}^{-1}$ in Heron, the earliest variety in the series, to $5.1 \mathrm{~m} \mathrm{plant}^{-1}$ in Mace, the most recent variety, at a rate of $0.08 \pm 0.008 \mathrm{~m} \mathrm{plant}^{-1} \mathrm{yr}^{-1}$. Under drought, total root length decreased from 7.3 to $3.8 \mathrm{~m} \mathrm{plant}^{-1}$ at a rate of $0.06 \pm 0.005 \mathrm{~m} \mathrm{plant}^{-1} \mathrm{yr}^{-1}$. Root biomass and root length density similarly declined with year of release under well-watered and drought conditions (Fig. 2b, c, Table 1). The decline in RLD with year of release was greater under well-watered conditions $\left(0.002 \pm 0.0002 \mathrm{~cm} \mathrm{~cm}^{-3} \mathrm{yr}^{-1}\right)$ than under drought $\left(0.001 \pm 0.0002 \mathrm{~cm} \mathrm{~cm}^{-3} \mathrm{yr}^{-1}\right)$ (Table 1$)$. The root: shoot ratio declined linearly with year of release under drought from 0.28 in Heron to 0.17 in Mace, at a rate of $0.002 \pm 0.0004 \mathrm{yr}^{-1}$ (Fig. 2d; Table 1). Under wellwatered conditions the root: shoot ratio showed no trend (Fig. 2d, Table 1).

\section{Shoot and root traits at anthesis}

At anthesis of each variety, leaf area declined linearly with year of release in well-watered and droughted plants (Fig. 3a, Table 2). Leaf area of well-watered plants declined from $826 \mathrm{~cm}^{2}$ plant $^{-1}$ in Heron to 655 $\mathrm{cm}^{2}$ plant $^{-1}$ in Mace at a rate of $3.9 \pm 0.62 \mathrm{~cm}^{2}$ plant $^{-1} \mathrm{yr}^{-1}$. Leaf area of droughted plants declined from 476 to $332 \mathrm{~cm}^{2}$ plant ${ }^{-1}$ at a rate of $2.9 \pm 0.49 \mathrm{~cm}^{2}$ plant $^{-1} \mathrm{yr}^{-1}$ (Table 2). The number of tillers and shoot biomass similarly declined linearly with year of release in well-watered and droughted plants (Fig. 3b; Table2). The decline in tiller number with year of release was sharper in well-watered plants $(0.08 \pm 0.011$ plant $\left.^{-1} \mathrm{yr}^{-1}\right)$ than droughted plants $\left(0.06 \pm 0.05\right.$ plant $\left.^{-1} \mathrm{yr}^{-1}\right)($ Table 2$)$.

Relative rate is the percentage of the newest variety.

Total root length, root biomass, root length density, and the root: shoot ratio at anthesis declined linearly with year of release in both well-watered and droughted plants (Fig. 3d-g, Table 2).

\section{Phenology}

Wheat varieties released between 1958 and 2012 emerged at 7-10 DAS under both watering regimes, with 1-3 d difference among the varieties. Time to $50 \%$ anthesis declined linearly with year of release in well-watered and droughted plants (Fig. 4a, Table 3). Time to anthesis in well-watered plants decreased from $103 \mathrm{~d}$ in Heron to $80 \mathrm{~d}$ in Mace, at a rate of $0.46 \pm 0.067 \mathrm{~d} \mathrm{yr} r^{-1}$. Time to anthesis in droughted plants 
declined from $91 \mathrm{~d}$ to $77 \mathrm{~d}$, at a rate of $0.28 \pm 0.026 \mathrm{~d} \mathrm{yr}^{-1}$ (Table 3). Time to physiological maturity (Z91) declined with year of release at similar rates in both watering regimes (Fig. 4b, Table 3). Duration of grain filling did not vary with year of release in well-watered plants (range: from $39 \mathrm{~d}$ in Condor to $42 \mathrm{~d}$ in Krichauff). In droughted plants, duration of grain filling decreased linearly with year of release from $42 \mathrm{~d}$ to $33 \mathrm{~d}$ at a rate of $0.13 \pm 0.009 \mathrm{~d} \mathrm{yr}^{-1}$ (Fig. 4c; Table 3)

\section{Grain yield and yield components}

Grain yield increased with year of release at a rate of $0.03 \pm 0.001 \mathrm{~g} \mathrm{plant}^{-1} \mathrm{yr}^{-1}\left(0.43 \pm 0.08 \% \mathrm{yr}^{-1}\right)$ under well-watered conditions and $0.026 \pm 0.001 \mathrm{~g} \mathrm{plant}^{-1} \mathrm{yr}^{-1}\left(0.35 \pm 0.082 \% \mathrm{yr}^{-1}\right)$ under drought (Fig. 5a; Table 3). Shoot biomass at final harvest showed no trend with year of release under both watering regimes (Fig. 5b; Table 3). Harvest index increased linearly with year of release at similar rates for well-watered and droughted plants (Fig. 5c, Table 3). Ear number, grain number, and grain weight did not vary with year of release irrespective of watering regime (Fig. $5 d-f$; Table 3 ).

The yield-based DSI (Eq. 1) decreased linearly with year of release from 0.43 in Heron to 0.26 in Mace, at a rate of $0.003 \pm 0.0003 \mathrm{yr}^{-1}$ (Fig. $5 \mathrm{~g}$, Table 3).

\section{Discussion}

Wheat breeding focuses primarily on yield, agronomic adaptation, grain quality, and disease resistance (Richards et al., 2014). This selective pressure leads to predictable changes in phenotype, such as increased $\mathrm{HI}$ (Slafer et al., 2021), and some unexpected shifts, such as reduction in root biomass compensated by increased nitrogen uptake per unit root length (Aziz et al., 2016). In our study, the phenotyping of a collection of wheat cultivars representing breeding efforts from 1958 to 2012 showed improved yield under early season drought associated with shifts in traits related to the plant's water economy and phenological development.

\section{Selection for yield favored an anisohydric phenotype}

The response to early season drought revealed a shift in the continuum from isohydric to anisohydric phenotypes (Tardieu and Simmonnea, 1998; Blum 2015). Older phenotypes reduced $g_{\mathrm{s}}$ and maintained $\Psi_{\text {leaf }}$ at the expense of photosynthesis and transpiration per unit leaf area, whereas newer varieties featured a more anisohydric phenotype with plant-level regulation of water use mediated by a reduction in leaf area, and maintenance of $g_{\mathrm{s}}$ photosynthesis and transpiration per unit leaf area at the expense of $\Psi_{\text {leaf. }}$ Similarly, Pima cotton (Gossypium barbadense L.) bred for higher yield potential had higher $g_{\mathrm{s}}$ and smaller leaf area than earlier lines (Lu et al., 1994).

We did not measure osmotic adjustment but hypothesize that osmotic adjustment might have contributed to the maintenance of $g_{\mathrm{s}}$ and leaf photosynthesis under decreasing $\Psi_{\text {leaf }}$ in newer phenotypes. Osmotic adjustment, which results from an active accumulation of solutes in response to 
decreasing $\Psi_{\text {leaf }}$ under water deficit (Turner and Jones, 1980), varies among wheat genotypes (Morgan and Condon, 1986; Morgan et al., 1986; Blum et al., 1999: Moinuddin et al., 2005). However, the marked reduction in leaf area of newer phenotypes under drought is evidence against superior osmoregulation (Blum 1989; Nio et al., 2011; 2018). Further experiments that measure osmotic potential are needed to solve these questions. The higher $g_{\mathrm{s}}$ of newer varieties under drought is a widespread response of crops to selection for yield (Roche 2015). In some crop-environment settings, high $g_{\mathrm{s}}$ has been interpreted as an adaptation to elevated temperature at the expense of water use efficiency (Radin et al., 1994; Lu et al ., 1994; Sadras et al., 2012b; Galat et al., 2020).

\section{Selection for yield favored smaller root system}

Consistent with Aziz et al. (2016), we found a decline in root length, root biomass, and root length density with year of release in well-watered plants. However, early season drought reduced root traits more markedly in older varieties than newer ones. Since drying soil often triggers seminal root growth that favors water uptake in some wheat genotypes (Palta and Gregory 1997; Whitmore and Whalley 2009; Hodgkinson et al., 2017), it is likely that, seminal roots of recent released varieties grew deeper in dery topsoil and slowed the decreasing rate with year of release. This is consistent with the early idea that phenotype must match the environment, and drought adaptation is associated with smaller root systems (Jordan and Miller 1980; Tardieu 2013).

Although plants exposed to early-season drought were well-watered after 32 DAS, the recovery of root length, root biomass and RLD at anthesis was unremarkable for all varieties. This was likely because root system growth, which usually peaks at flowering (Gregory and Atwell 1991; Gregory et al., 1995; Palta and Gregory 1997), run-off time as time to anthesis shortened. Moreover, wheat genotypes with longer time to anthesis have larger root growth (total root length and root biomass) at maturity than those with shorter time to anthesis (Motzo et al., 1993; Aziz et al., 2016; Figueroa Bustos et al., 2019, 2020)

\section{Selection for yield reduced phenological response to drought}

Early field studies with a similar collection of varieties revealed no trend in time to flowering with year of release (Sadras and Lawson, 2011, 2013). In contrast, our glasshouse study showed earlier flowering in newer varieties in the well-watered treatment. The regressions between time to flowering and year of release converged between well-watered and droughted plants. Older varieties had a marked shortening of time to flowering in response to drought, whereas newer varieties were less responsive, despite being more stressed. In contrast, two independent studies under field and glasshouse conditions have reported delayed anthesis of wheat in response to early-season drought (French and Palta 2014; Figueroa Bustos et al., 2019). The non-linear response of wheat phenology to water stress could explain these contradictory responses. Angus and Moncur (1977) found that time from flower initiation to anthesis shortened under mild water stress $\left(\Psi_{\text {leaf }}-1.5 \mathrm{MPa}\right)$ and delayed with severe stress $\left(\Psi_{\text {leaf }}-2.5 \mathrm{MPa}\right)$. In our study, a mild stress ( $\left.\Psi_{\text {leaf }}-1.8\right)$ shortened time to flowering, whereas more severe stress $\left(\Psi_{\text {leaf }}-2.5\right.$ $\mathrm{MPa}$ ) delayed flowering in Figueroa Bustos et al. (2019). Our findings highlight the need for simulation 
modeling to account for genotype-dependent phenological response to water deficit (Chauhan et al., 2019; McMaster et al., 2013) because mainstream crop models do not (Wallach et al., 2021). Overlooking the effect of plant water status on phenology can therefore bias predictions of crop adaptation to future climates, including early-season drought.

The shortening of grain filling with drought often reduces $\mathrm{HI}$ and yield (Kobata et al., 1992; He and Rajaram, 1993; Wheeler et al., 1996). In our experiment, drought older maintained the duration of grain filling in older varieties but shortened it in newer on. However, drought did not affect $\mathrm{HI}$, might be partially related to the higher amount of reserve carbohydrates and/or faster rates of remobilization to the grain in newer varieties (Kobata et al., 1992; Palta et al., 1994). This highlights that phenology, particularly shortened time to anthesis, limited the recovery of shoot biomass and grain yield in response to early season drought.

As reported in Aziz et al. (2017), the root system of wheat varieties released in Australia between 1958 and 2012 progressively reduced their root length, root biomass, and RLD with year of release, but early season drought slowed the rate of decline in these traits. Since drying soil often triggers seminal root growth in some wheat genotypes (Palta and Gregory 1997; Whitmore and Whalley 2009; Hodgkinson et al., 2017), seminal root tips of recent varieties likely grew deeper than older varieties with decreasing soil water content in the topsoil layer, and this additional root growth slow down the rate of declining in root length, root biomass and RLD with year of release.

Early season drought reduced root length, root biomass, and RLD, less so in the varieties released after 1997 (Wyalkatchem, Gladius, Mace) than earlier varieties (Heron, Halberd, and Condor). This was likely because the recent varieties kept leaf photosynthesis and transpiration rate and reduced leaf area during early drought, with more available carbon assimilates for root growth, when the demand of daily carbon assimilates for wheat root system growth and proliferation was high (Gregory and Atwell 1990; Palta and Gregory 1997).

Under early season drought, the root: shoot ratio decreased linearly with year of release, following the linear decrease in root biomass rather than shoot biomass, but there was no such trend with year of release under well-watered conditions. The linear decrease in root: shoot ratio with year of release was consistent with the linear increase in leaf transpiration rate with year of release under early season drought, indicating that the high root: shoot ratio (high root density) favored a higher transpiration rate (Saidi et al., 2010; Vadez et al., 2021).

\section{Conclusions}

Wheat varieties released in Australia between 1958 and 2012, exposed to early-season drought after leaf emergence, progressively increased grain yield with year of release. The decreasing susceptibility to early season drought with year of release was associated with a shift from isohydric to anisohydric phenotypes and distinct phenological adaptation to dry soil. The higher $\mathrm{g}_{\mathrm{s}}$ and leaf photosynthesis rate 
of anisohydric varieties contributed to the increased grain yield with year of release since the early water deficit was moderate with $\Psi_{\text {leaf }}$ down to -1.8 (Alvarez et al., 2007; Sade et al., 2009). The wheat collection used in this study is a suitable model to further investigate the phenotypic response to drought, including the dual role of labile carbohydrates in osmoregulation and as a buffer for grain fill and its genetic basis.

\section{Declarations}

\section{Acknowledgments}

We thank Mr. Robert Creasy and Mr. Bill Piasini for technical assistance in the glasshouse experiment, and Prof. Neil C Turner for discussion on the data. This research was supported by The University of Western Australia (UWA). The Higher Education Commission of Pakistan and the China Scholarship Council provided financial support to Mr. Faisal Khan and Mr. Yupeng Feng, respectively, for their training visits to UWA.

\section{References}

1. Alvarez E, Scheiber SM, Beeson RC, Jr, Sandrock DR (2007) Drought tolerance responses of purple Lovegrass and 'Adagio'maiden grass. HortScience42:1695-1699

2. Angus JF, Moncur MW (1977) Water stress and phenology in wheat. Aust J Agric Res 28: 177-181.

3. Armstrong LJ, Abrecht DG, Anderson WK, Belford RK (1996) The effect of non-lethal water deficits during establishment on the growth of wheat crops. Proceedings of the 8th Australian Agronomy Conference, Toowoomba, Queensland, Australia, 30 January-2 February, 1996. Australian Society of Agronomy Inc., Toowoomba, Australia.

4. Austin RB, Bingham J, Blackwell RD, Evans LT, Ford MA, Morgan CL, Taylor M (1980) Genetic improvements in winter wheat yields since 1900 and associated changes. J Agricul Sci 94: 675-689.

5. Austin RB (1990) Prospects for genetically increasing the photosyntheticcapacity of crops In 'Perspectives in biochemical and genetic regulationof photosynthesis'. Vol. 1. (Ed. Y Zelith) pp. 395409. (Alan R. Liss:New York)

6. Aziz MM, Palta JA, Siddique KHM, Sadras VO. 2017. Five decades of selection for yield reduced root length density and increased nitrogen uptake per unit root length in Australian wheat varieties. Plant Soil413 (1-2): 181-192.

7. Blum A (1989) Osmotic adjustment and growth of barley genotypes under drought stress. Crop Sci $29,230-233$.

8. Blum A, Zhang J, Nguyen HT (1999) Consistent differences among wheat cultivars in osmotic adjustment and their relationship. Field Crops Res 64:287-291.

9. Blum A (2015) Towards a conceptual ABA ideotype in plant breeding for water limited environments. Funct Plant Biol 42:502-513. 
10. Cann DJ, Schillinger WF, Hunt JR, Porker KD, Harris FAJ (2020) Agroecological Advantages of earlysown winter wheat in semi-arid environments: A comparative case study from southern Australia and pacific northwest United States. Frontiers Plant Sci 11: 568.

11. Chapman R, Asseng S (2001) An analysis of the frequency and timing of false break events in the Mediterranean region of Western Australia. Aust J Agricul Res52(3): 367-376.

12. ChauhanYS, Ryan M, Chandra S. et al. (2019) Accounting for soil moisture improves prediction of flowering time in chickpea and wheat. Sci Rep 9: 7510. https://doi.org/10.1038/s41598-019-43848-6

13. Chenu K, Deihimfard R, Chapman SC (2013) Large-scale characterization of drought pattern: A continent-wide modelling approach applied to the Australian wheatbelt - spatial and temporal trends. New Phytol198: 801-820.

14. Chenu K (2015) Characterising the crop environment - nature, significance and applications. In: V. O. SadrasD. F. Calderini eds. Crop physiology: Applications for genetic improvement and agronomy. San Diego: Academic Press,321-348.

15. Cossani CM, Sadras VO (2019) Increasing co-limitation of water and nitrogen drives genetic yield gain in Australian wheat. Europ J Agron 106: 23-29.

16. Cossani CM, Sadras VO (2021) Symmetric response to competition in binary mixtures of cultivars associates with genetic gain in wheat yield. Evol Appl 14:2064-2078

17. Figueroa-Bustos VF, Palta JA, Chen Y, Siddique KHM (2019) Early season drought largely reduces grain yield in wheat cultivars with smaller root systems. Plants 8(9): 1-15.

https://doi.org/10.3390/plants8090305

18. Figueroa-Bustos V, Palta JA, Chen Y, Stefanova K, Siddique KHM (2020) Contrasting root system size wheat genotypes responded differently to terminal drought. Frontiers Plant Sci.

https://doi.10.3389/fpls.2020.01285.

19. Fischer R, Maurer R (1978) Drought resistance in spring wheat cultivars. I. Grain yield responses. Aust J Agric Res 29: 897-912.http://dx.doi.org/10.1071/AR9780897

20. Fischer RA, Byerlee D, Edmeades GO (2014) Crop yields and global food security. Will yield increase continue to feed the world? Canberra: ACIAR.

21. Fletcher A, Lawes $R$, Weeks C (2016) Crop area increases drive earlier and dry sowing in Western Australia: Implications for farming systems. Crop Pasture Sci 67: 1268-1280. doi: 10.1071/CP16200.

22. Fletcher AL, Robertson MJ, Abrecht DG, Sharma DL, Holzworth DP (2015) Dry sowing increases farm level wheat yields but not production risks in a Mediterranean environment. Agric Syst 136: 114-124. doi: 10.1016/j. agsy.2015.03.004

23. Flower KC, Cordingley N, WardPR, Weeks C (2012) Nitrogen, weed management and economics with cover crops in conservation agriculture in a Mediterranean climate. Field Crops Res 132: 63-75. doi: 10.1016/j.fcr.2011.09.011

24. French B, Palta JA (2014) Early vigour avoids drought stress. GRDC Ground Cover 112, 71-74. 
25. Galat Giorgi E, Keller M, Sadras V, Roig FA, Perez Peña J (2020) High temperature during the budswell phase of grapevines increases shoot water transport capacity. Agric Forest Meteorol 295:108173

26. Greenland S (2019) Valid P-values behave exactly as they should: Some misleading criticisms of Pvalues and their resolution with S-values.American Statist 73: 106-114.

27. Gregory PJ, Atwell BJ (1991) The fate of carbon in pulse-labelled crops of barley and wheat. Plant Soil 136: 205-213. https://doi.org/10.1007/BF02150051

28. Gregory PJ, Palta JA, Batts GR (1995) Root systems and root:mass ratio-carbon allocation under current and projected atmospheric conditions in arable crops. Plant Soil 187: 221-228. https://doi.org/10.1007/BF00017089.

29. He Z, Rajaram S (1993) Differential responses of bread wheat characters to high temperature. Euphytica 72: 197-203. doi:10.1007/BF0003415

30. Hochman Z, Gobbett DL, Horan H (2017) Climate trends account for stalled wheat yields in Australia since 1990. Glob Change Biol 23: 2071-2081.

31. doi: $10.1111 /$ gcb.13604.

32. Hodgkinson L, Dodd IC, Binley A, Ashton RW, White RP, Watts CW, Whalley WR (2017) Root growth in field-grown winter wheat: Some effects of soil conditions, season and genotype. Europ J Agron 91:74-83

33. Isbell RF (1993) A classification system for Australian soils (third approximation). Technical Report 2/1993 Australia, CSIRO.

34. Jordan WR, Miller MR (1980) Genetic variability in sorghum root system: Implications for drought tolerance. In: N. C. TurnerP. J. Kramer eds. Adaptation of plants to water and high temperature stress. New York: John Wiley and Sons,383-399.

35. Kobata T, Palta JA, Turner NC (1992) Rate of development of postanthesis water deficits and grain filling of spring wheat. Crop Sci 32: 1238-1242. doi:10.2135/cropsci1992.0011183X003200050035x

36. Lemerle D, Cousens RD, Gill GS, Peltzer SJ, Moerkerk M, Murphy CE, Collins D, Cullis BR (2004) Reliability of higher seeding rates of wheat for increased competitiveness with weeds in low rainfall environments. J Agric Sci 142: 395-409

37. Radin JW, Lu Z, Percy RG, Zeiger E (1994) Genetic variability for stomatal conductance in Pima cotton and its relation to improvements of heat adaptation. Proceedings National Acad Sci, U.S.A. 91:7217-7221

38. Liao M, Fillery IRP, Palta JA (2004) Early vigorous growth is a major factor influencing nitrogen uptake in wheat. Funct Plant Biol 31: 121-129.

39. Lu Z, Radin JW, Turcotte EL, Percy R, Zeiger E (1994) High yields in advanced lines of Pima cotton are associated with higher stomatal conductance, reduced leaf area and lower leaf temperature. Physiologia Plantarum 92:266-272 
40. McMaster GS, Ascough JCII, Edmunds DA, Nielsen DC, Prasad PV (2013) Simulating crop phenological responses to waterstress using the PhenologyMMS software program. Appl EngineerAgricul 29: 233-249.

41. Moinuddin, Fischer RA, Sayre KD, Reynolds MP (2005) Osmotic adjustment in wheat in relation to grain yield under water deficit environments. AgronJ 197: 1061-1071

42. Morgan JM, Condon AG (1986) Water use, grain yield and types for water deficit environments, using greenhouse osmoregulation in wheat. Aust J Plant Physiol 13:523-532.

43. Morgan JM, Hare RA, Fletcher RJ (1986) Genetic variation in osmoregulation in bread and durum wheats and its relationship to grain yield in a range of field environments. Aust $\mathrm{J}$ Agric Res37:449457.

44. Motzo R, Attene G, Deidda M (1993) Genotypic variation in durum wheat root systems at different stages of development in a Mediterranean environment. Euphytica 66: 197-206.

45. Nio SA, Cawthray GR, Wade LJ, Colmer TD (2011) Pattern of solutes accumulated during leaf osmotic adjustment as related to duration of water deficit for wheat at the reproductive stage. Plant Physiol Biochem 49:1126-1137

46. Nio Al, Mantilen-Ludong DP, Wade L (2018) Comparison of leaf osmotic adjustment expression in wheat (Triticum aestivum L.) under water deficit between the whole plant and tissue levels. Agri Nat Res 52:33-38

47. Palta JA, Fillery IR (1993) Nitrogen accumulation and remobilisation in wheat of $15 \mathrm{~N}$-urea applied to a duplex soil at seeding. Aust J Exp Agric 33: 233-238.

48. Palta JA, Gregory PJ (1997) Drought affects the fluxes of carbon to roots and soil in $13 \mathrm{C}$ pulselabelled plants of wheat. Soil Biol Biochem 29: 1395-1403.

49. Pook M, Lisson S, Risbey J, Ummenhofer CC,McIntosh P, Rebbeck M (2009) The autumn break for cropping in southeast Australia: trends, synopticinfluences and impacts on wheat yield. Int $\mathrm{J}$ Climatol 29:2012-2026.

50. Richards RA, Hards RA, Hunt JR, Kirkegaard JA, Passioura JB (2014) Yield improvement and adaptation of wheat to water-limited environments in Australia-a case study. Crop \& Pasture Science, 65, 676-689.

51. Roche D (2015) Stomatal conductance is essential for higher yield potential of C3 crops. Critical Rev Plant Sci34:429-453

52. Sade N, Vinocur BJ, Diber A, Shatil A, Ronen G, Nissan H (2009) Improving plant stress tolerance and yield production: is the tonoplast aquaporin SITIP2;2 a key to isohydric to anisohydric conversion? New Phytol 181:651-61http://dx.doi. org/10.1111/j.1469-8137.2008.02689.x

53. Sadras VO, Lawson C (2011) Genetic gain in yield and associated changes in phenotype, trait plasticity and competitive ability of South Australian wheat varieties released between 1958 and 2007. Crop Pasture Sci62: 533-549.

54. Sadras VO, Lawson C, Montoro A. (2012a). Photosynthetic traits of Australian wheat varieties released between 1958 and 2007. Field Crops Res 134: 19-29. 
55. Sadras VO, Montoro A, Moran MA, Aphalo PJ (2012b) Elevated temperature altered the reaction norms of stomatal conductance in field-grown grapevine. Agri Forest Meteorol 165:35-42

56. Sadras VO, Lawson C (2013) Nitrogen and water-use efficiency of Australian wheat varieties released between 1958 and 2007. Europ J Agron 46: 34-41

57. Saidi A, Ookawa T, Hirasawa T (2010) Responses of root growth to moderate soil water deficit in wheat seedlings, Plant Produc Sci 13:3, 261-268, DOI: 10.1626/pps.13.261

58. Shiferaw B, Smale M, Braun H-J, Duveiller E, Reynolds M, Muricho G (2013) Crops that feed the world 10. Past successes and future challenges to the role played by wheat in global food security. Food Security 5(3): 291-317.

59. Slafer GA (1994) Genetic improvement of field crops. New York: Marcel Dekker Inc.

60. Slafer GA, Savin R, Pinochet D, Calderini D (2021) Wheat. In: Sadras VO, Calderini DF (eds) Crop Physiology: Case Histories for Major Crops. Academic Press, pp 99-163

61. Tardieu F, Simonneau T (1998) Variability among species of stomatal control under fluctuating soil water status and evaporative demand: modelling isohydric and anisohydric behaviours. J Exp Bot 49:419-432. doi:10.1093/jxb/49.

62. Tardieu F (2012) Any trait or trait-related allele can confer drought tolerance: Just design the right drought scenario. J Exp Bot63 (1): 25-31.

63. Tardieu $\mathrm{F}$ (2013). Plant response to environmental conditions: assess-ing potential production, water demand, and negative effects of waterdeficit. Front Physiol4:17

64. Turner NC (1988) Measurement of plant water status by the pressure chamber technique. Irrigation Sci 9: 289-308.

65. Turner NC, Jones MM (1980) Turgor maintenance by osmotic adjustment: a review and evaluation. In: Turner NC, Kramer PJ, eds. Adaptation of plants to water and high temperature stress. New York: Wiley, 87-103.

66. Vadez V, Choudhary S, Kholová J, Hash CT, Srivastava R, Kumar AA, Prandavada A, Anjaiah M (2021) Transpiration efficiency: insights from comparisons of C4 cereal species, J ExpBot 72: 221-5234.

67. https://doi.org/10.1093/jxb/erab251

68. Wallach D, Palosuo T, Thorburn P, Gourdain E, Asseng S, Basso B, Buis S, Crout N, Dibari C, Dumont B, Ferrise R. (2021) How well do crop modeling groups predict wheat phenology, given calibration data from the target population? Europ J Agron124: 126195. doi:https://doi.org/10.1016/j.eja.2020.126195, 2021.

69. Watson J, Zheng BY, Chapman S, Chenu K (2017) Projected impact of future climate on water-stress patterns across the australian wheatbelt. J Exp Bot68 (21-22): 5907-5921.

70. Wheeler TR, Hong TD, Ellis RH, Batts GR, Morison JIL, Hadley P (1996) The duration and rate of grain growth, and harvest index, of wheat (Triticum aestivum L.) in response to temperature and $\mathrm{CO}_{2} . . \mathrm{J}$ Exp Bot 47:623-630. 
71. Whitmore AP, Whalley WR (2009) Physical effects of soil drying on roots and crop growth. J Exp Bot60(10):2845-57. doi: 10.1093/jxb/erp200. PMID: 19584120.

72. Zadoks JC, Chang TTK, Konzak CF (1974) A decimal code for the growth stages of cereals. Weed Res 14: 415-421.

\section{Tables}

Table 1. Absolute and relative rate of change ( \pm s.e.) for traits of Australian wheat varieties released from 1958 to 2012 grown in $1 \mathrm{~m}$ deep PVC columns under early season drought (ESD) and well-watered conditions (WW). Measurements were made at 32 days after sowing, just before the end of the ESD treatment. Rates and $p$-values are from the least-square regression between trait and year of release. Relative rate is the percentage of the newest variety. 


\begin{tabular}{|c|c|c|c|c|}
\hline \multirow[t]{2}{*}{ Traits } & \multirow[t]{2}{*}{ Treatment } & \multirow{2}{*}{$\begin{array}{l}p- \\
\text { value }\end{array}$} & \multicolumn{2}{|l|}{ Rate of change } \\
\hline & & & Absolute & $\begin{array}{l}\text { Relative } \\
\left(\% \mathrm{yr}^{-1}\right)\end{array}$ \\
\hline \multirow{2}{*}{$\begin{array}{l}\text { Volumetric } \\
\text { soil water content }\end{array}$} & $\overline{\mathrm{WW}}$ & \multirow{4}{*}{$\begin{array}{l}0.2561 \\
0.0001 \\
0.739 \\
0.012\end{array}$} & $-0.0127 \pm 0.010 \% \mathrm{yr}^{-1}$ & $-0.0847 \pm 0.0678$ \\
\hline & ESD & & $-0.3085 \pm 0.001 \% \mathrm{yr}^{-1}$ & $-0.3085 \pm 0.0209$ \\
\hline \multirow{2}{*}{$\begin{array}{l}\text { Leaf } \\
\text { water potential }\end{array}$} & WW & & $-0.0005 \pm 0.001 \mathrm{MPa} \mathrm{yr}^{-1}$ & $-0.0663 \pm 0.1742$ \\
\hline & ESD & & $-0.0080 \pm 0.002 \mathrm{MPa} \mathrm{yr}^{-1}$ & $0.4480 \pm 0.1425$ \\
\hline \multirow[t]{2}{*}{$\begin{array}{l}\text { Stomatal } \\
\text { conductance }\end{array}$} & WW & \multirow{2}{*}{$\begin{array}{l}0.9873 \\
0.0041\end{array}$} & $\begin{array}{l}0.0002 \pm 0.0008 \mathrm{~mol} \mathrm{H}_{2} \mathrm{O} \mathrm{m}^{-2} \mathrm{~s}^{-1} \\
\mathrm{yr}^{-1}\end{array}$ & $0.0093 \pm 0.2281$ \\
\hline & ESD & & $\begin{array}{l}0.0016 \pm 0.0003 \mathrm{~mol} \mathrm{H}_{2} \mathrm{O} \mathrm{m}^{-2} \mathrm{~s}^{-1} \\
\mathrm{yr}^{-1}\end{array}$ & $1.3947 \pm 0.2405$ \\
\hline \multirow[t]{2}{*}{$\begin{array}{l}\text { Leaf } \\
\text { photosynthesis } \\
\text { rate }\end{array}$} & $\overline{\text { WW }}$ & \multirow{2}{*}{$\begin{array}{l}0.7593 \\
0.0001\end{array}$} & $\begin{array}{l}0.0125 \pm 0.039 \mu \mathrm{mol} \mathrm{CO} \mathrm{CO}^{-2} \mathrm{~s}^{-1} \\
\mathrm{yr}^{-1}\end{array}$ & $0.1262 \pm 0.3335$ \\
\hline & ESD & & $\begin{array}{l}0.0790 \pm 0.011 \mu \mathrm{mol} \mathrm{CO} \mathrm{m}^{-2} \mathrm{~s}^{-1} \\
\mathrm{yr}^{-1}\end{array}$ & $1.0136 \pm 0.1507$ \\
\hline \multirow[t]{2}{*}{$\begin{array}{l}\text { Leaf transpiration } \\
\text { rate }\end{array}$} & $\overline{\text { WW }}$ & \multirow{2}{*}{0.2412} & $\begin{array}{l}0.0216 \pm 0.017 \mathrm{mmol} \mathrm{H}_{2} \mathrm{O} \mathrm{m}^{-2} \mathrm{~s}^{-} \\
{ }^{1} \mathrm{yr}^{-1}\end{array}$ & $0.4512 \pm 0.3539$ \\
\hline & ESD & & $\begin{array}{l}0.0323 \pm 0.095 \mathrm{mmol} \mathrm{H}_{2} \mathrm{O} \mathrm{m}^{-2} \mathrm{~s}^{-} \\
{ }^{1} \mathrm{yr}^{-1}\end{array}$ & $0.9485 \pm 0.1900$ \\
\hline \multirow[t]{2}{*}{ Leaf area } & $\overline{W W}$ & 0.8048 & $-0.069 \pm 0.270 \mathrm{~cm}^{2}$ plant $^{-1} \mathrm{yr}^{-1}$ & $-0.0975 \pm 0.2955$ \\
\hline & ESD & 0.0009 & $-0.583 \pm 0.114 \mathrm{~cm}^{2}$ plant $^{-1} \mathrm{yr}^{-1}$ & $-1.9181 \pm 0.3881$ \\
\hline \multirow[t]{2}{*}{ Tiller number } & $\overline{W W}$ & 0.0001 & $-0.033 \pm 0.004$ plant $^{-1} \mathrm{yr}^{-1}$ & $-3.4154 \pm 0.4105$ \\
\hline & ESD & 0.0064 & $-0.012 \pm 0.003$ plant $^{-1} \mathrm{yr}^{-1}$ & $-2.3816 \pm 0.6297$ \\
\hline \multirow[t]{2}{*}{ Shoot biomass } & WW & 0.0055 & $-0.0020 \pm 0.0006 \mathrm{~g} \mathrm{plant}^{-1} \mathrm{yr}^{-1}$ & $-1.1021 \pm 0.2983$ \\
\hline & ESD & 0.5789 & $-0.0002 \pm 0.0002 \mathrm{~g} \mathrm{plant}^{-1} \mathrm{yr}^{-1}$ & $-0.1106 \pm 0.1897$ \\
\hline \multirow[t]{2}{*}{ Root length } & WW & 0.0001 & $-0.0849 \pm 0.008 \mathrm{~m} \mathrm{plant}^{-1} \mathrm{yr}^{-1}$ & $-1.6306 \pm 0.1697$ \\
\hline & ESD & 0.0001 & $-0.0591 \pm 0.005 \mathrm{~m} \mathrm{plant}^{-1} \mathrm{yr}^{-1}$ & $-1.5270 \pm 0.1402$ \\
\hline \multirow[t]{2}{*}{ Root biomass } & $\overline{W W}$ & 0.0001 & $-0.0005 \pm 0.00006 \mathrm{~g} \mathrm{plant}^{-1} \mathrm{yr}^{-1}$ & $-1.8145 \pm 0.2103$ \\
\hline & ESD & 0.0001 & $-0.0004 \pm 0.00003 \mathrm{~g} \mathrm{plant}^{-1} \mathrm{yr}^{-1}$ & $-1.3254 \pm 0.1009$ \\
\hline \multirow{2}{*}{$\begin{array}{l}\text { Root length } \\
\text { density }\end{array}$} & $\overline{\text { WW }}$ & \multirow{4}{*}{$\begin{array}{l}0.0001 \\
0.0001 \\
0.1222 \\
0.0009\end{array}$} & $-0.0024 \pm 0.0002 \mathrm{~cm} \mathrm{~cm}^{-3} \mathrm{yr}^{-1}$ & $-1.6306 \pm 0.1697$ \\
\hline & ESD & & $-0.0017 \pm 0.0002 \mathrm{~cm} \mathrm{~cm}^{-3} \mathrm{yr}^{-1}$ & $-1.5270 \pm 0.1402$ \\
\hline \multirow[t]{2}{*}{ Root: shoot ratio } & $\overline{W W}$ & & $-0.0006 \pm 0.0003 \mathrm{yr}^{-1}$ & $-1.1321 \pm 0.2213$ \\
\hline & ESD & & $-0.0020 \pm 0.0004 \mathrm{yr}^{-1}$ & $-0.4242 \pm 0.2455$ \\
\hline
\end{tabular}

$\begin{array}{lllllllllll}0 & 0.1 & 0.2 & 0.3 & 0.4 & 0.5 & 0.6 & 0.7 & 0.8 & 0.9 & 1\end{array}$

Color scale for $p$-values 
Table 2. Absolute and relative rates of change for traits of Australian wheat varieties released from 1958 to 2012 grown in $1 \mathrm{~m}$ deep PVC columns under early season drought (ESD) and well-watered conditions (WW). Measurements were made at $50 \%$ anthesis of each cultivar. Rates and $p$-values are from the least-square regression between trait and year of release. Relative rate is the percentage of the newest variety.

\begin{tabular}{|c|c|c|c|c|}
\hline Traits & Treatment & $p$-values & \multicolumn{2}{|c|}{ Rates of change } \\
\hline & & & Absolute & $\begin{array}{l}\text { Relative } \\
\left(\% \mathrm{yr}^{-1}\right)\end{array}$ \\
\hline \multirow[t]{2}{*}{ Leaf area } & WW & 0.0002 & $-3.91 \pm 0.62 \mathrm{~cm}^{2}$ plant $^{-1} \mathrm{yr}^{-1}$ & $-0.7531 \pm 0.2579$ \\
\hline & ESD & 0.0003 & $-2.97 \pm 0.49 \mathrm{~cm}^{2}$ plant $^{-1} \mathrm{yr}^{-1}$ & $-0.8919 \pm 0.3454$ \\
\hline \multirow[t]{2}{*}{ Tiller number } & WW & 0.0001 & $-0.085 \pm 0.011$ plant $^{-1} \mathrm{yr}^{-1}$ & $-2.1836 \pm 0.2993$ \\
\hline & ESD & 0.0001 & $-0.059 \pm 0.049$ plant $^{-1} \mathrm{yr}^{-1}$ & $-2.4325 \pm 0.2037$ \\
\hline \multirow[t]{2}{*}{ Shoot biomass } & WW & 0.0086 & $-0.042 \pm 0.012$ g plant $^{-1} \mathrm{yr}^{-1}$ & $-0.9169 \pm 0.2418$ \\
\hline & ESD & 0.0039 & $-0.040 \pm 0.010$ g plant $^{-1} \mathrm{yr}^{-1}$ & $-1.1328 \pm 0.2433$ \\
\hline \multirow[t]{2}{*}{ Root length } & WW & 0.0002 & $-0.506 \pm 0.075 \mathrm{~m} \mathrm{plant}^{-1} \mathrm{yr}^{-1}$ & $-1.0034 \pm 0.1503$ \\
\hline & ESD & 0.0001 & $-0.244 \pm 0.033 \mathrm{~m} \mathrm{plant}^{-1} \mathrm{yr}^{-1}$ & $-1.4769 \pm 0.1999$ \\
\hline \multirow[t]{2}{*}{ Root biomass } & WW & 0.0004 & $-0.013 \pm 0.002 \mathrm{~g} \mathrm{plant}^{-1} \mathrm{yr}^{-1}$ & $-2.2122 \pm 0.3795$ \\
\hline & ESD & 0.0001 & $-0.007 \pm 0.0009$ g plant $^{-1} \mathrm{yr}^{-1}$ & $-3.0177 \pm 0.3596$ \\
\hline \multirow[t]{2}{*}{ Root length density } & WW & 0.0002 & $-0.006 \pm 0.0009 \mathrm{~cm} \mathrm{~cm}^{-3} \mathrm{yr}^{-1}$ & $-1.0034 \pm 0.1503$ \\
\hline & ESD & 0.0001 & $-0.003 \pm 0.0004 \mathrm{~cm} \mathrm{~cm}^{-3} \mathrm{yr}^{-1}$ & $-1.4769 \pm 0.1999$ \\
\hline \multirow[t]{2}{*}{ Root: Shoot ratio } & WW & 0.0030 & $-0.001 \pm 0.0002 \mathrm{yr}^{-1}$ & $-1.0294 \pm 0.2456$ \\
\hline & ESD & 0.0008 & $-0.0009 \pm 0.0002 \mathrm{yr}^{-1}$ & $-1.5635 \pm 0.2977$ \\
\hline
\end{tabular}

\section{$\begin{array}{lllllllllll}0 & 0.1 & 0.2 & 0.3 & 0.4 & 0.5 & 0.6 & 0.7 & 0.8 & 0.9 & 1\end{array}$}

Color scale for $p$-values

Table 3. Absolute and relative rates of change for traits of Australian wheat varieties released from 1958 to 2012 grown in $1 \mathrm{~m}$ deep PVC columns under early-season drought (ESD) and well-watered conditions (WW). Measurements were made at final harvest. Rates and $p$-values are from the least-square regression between trait and year of release. Relative rate is the percentage of the newest variety. 


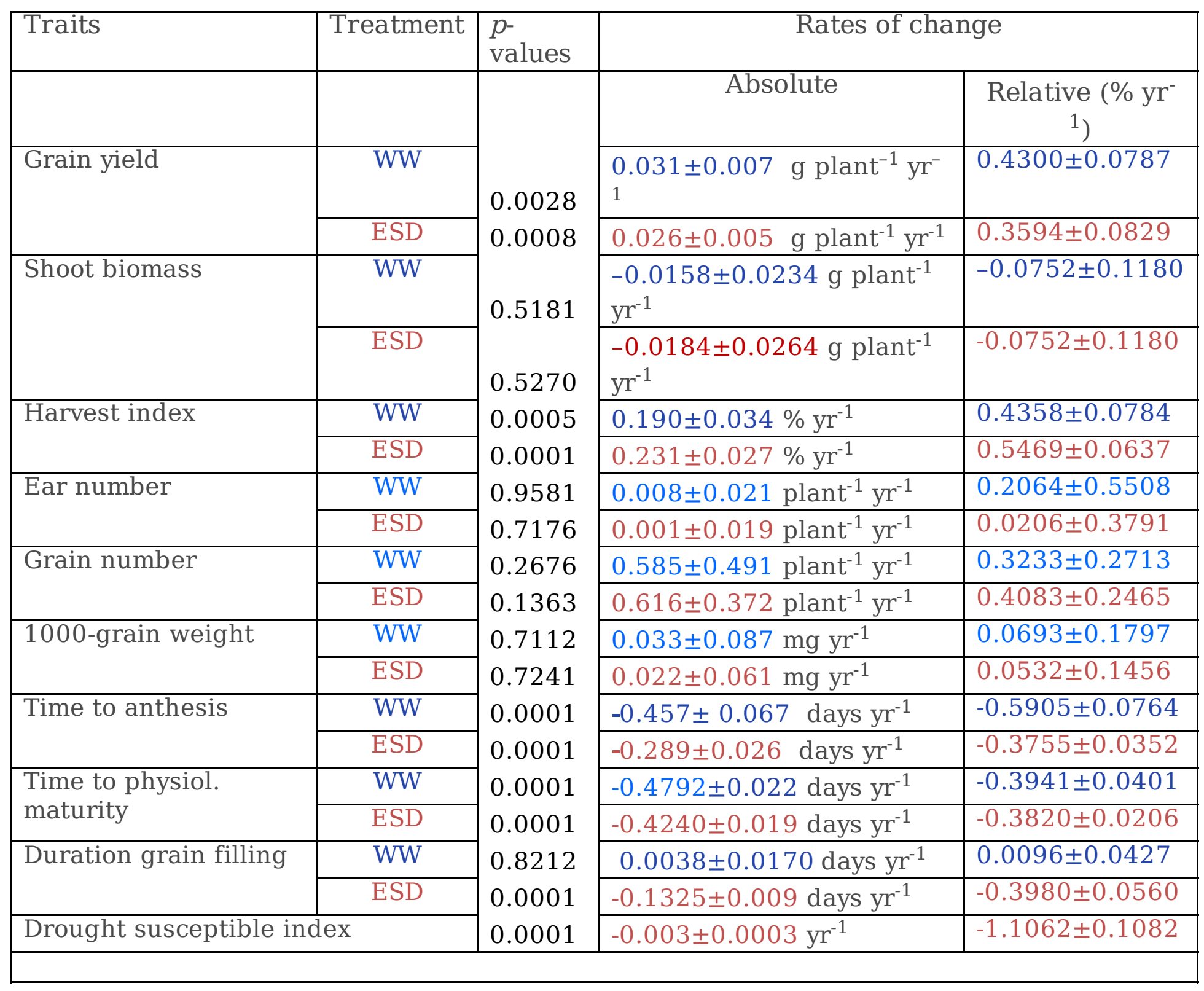

\section{$\begin{array}{lllllllllll}0 & 0.1 & 0.2 & 0.3 & 0.4 & 0.5 & 0.6 & 0.7 & 0.8 & 0.9 & 1\end{array}$}

Color scale for $p$-values

\section{Figures}



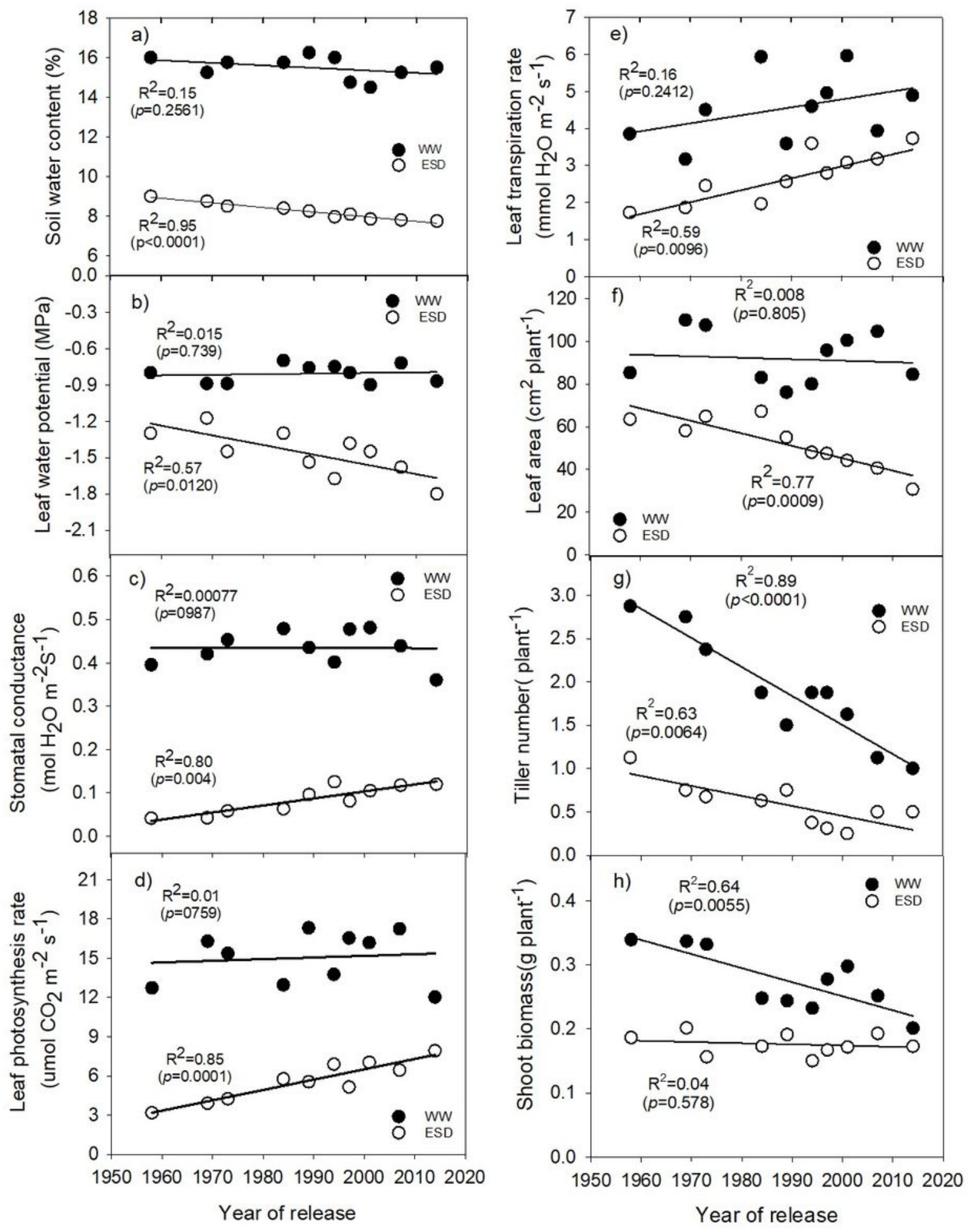

\section{Figure 1}

Soil water content, plant water status, leaf gas-exchange, leaf area, tiller number and shoot biomass of Australian wheat varieties released from 1958 to2012 grown in $1 \mathrm{~m}$ deep PVC columns under earlyseason drought (ESD) and well-watered (WW) conditions. Measurements were made at 32 days after sowing, just before the end of the ESD treatment. Values are the mean of four replicate columns(two plants per column)per variety per year of release. 


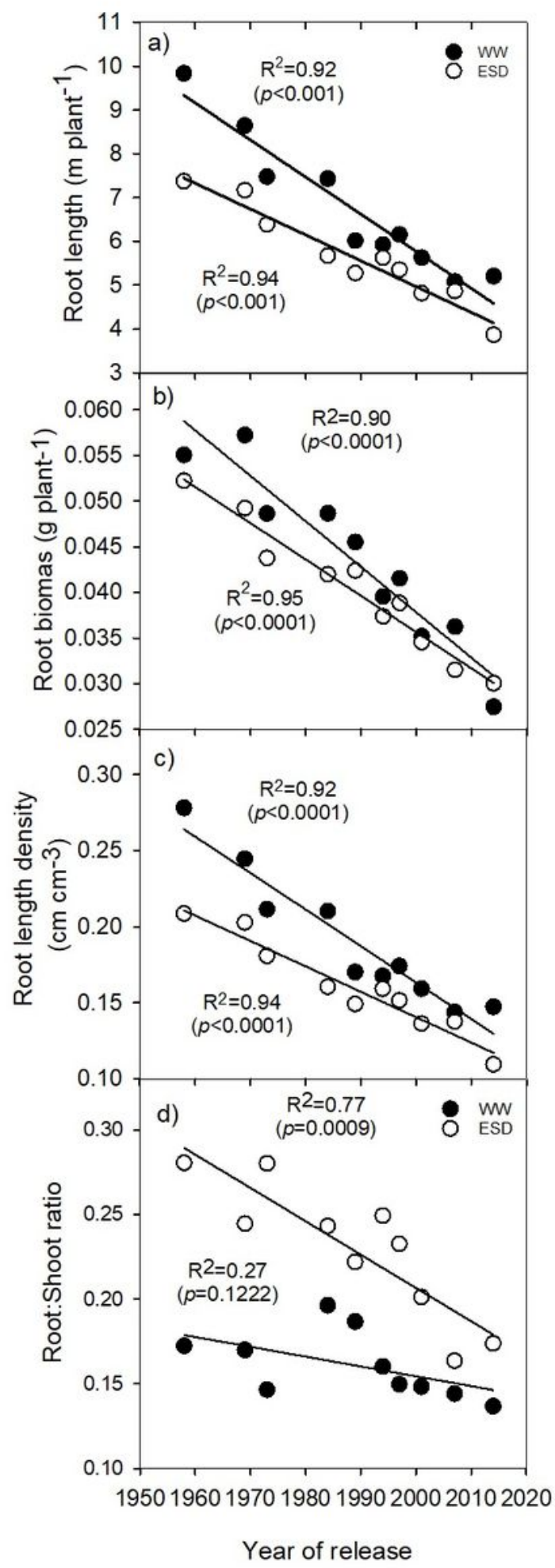

\section{Figure 2}

Total root length and root biomass, root length density (RLD) and root: shoot ratio of Australian wheat varieties released from 1958 to2012 grown in $1 \mathrm{~m}$ deep PVC columns under earlyseason drought (ESD) and well-watered (WW)conditions. Measurements were made at 32 days after sowing, just before the end of the ESD treatment. Values are the mean of four replicate column (two plants per column)per variety per year of release. 

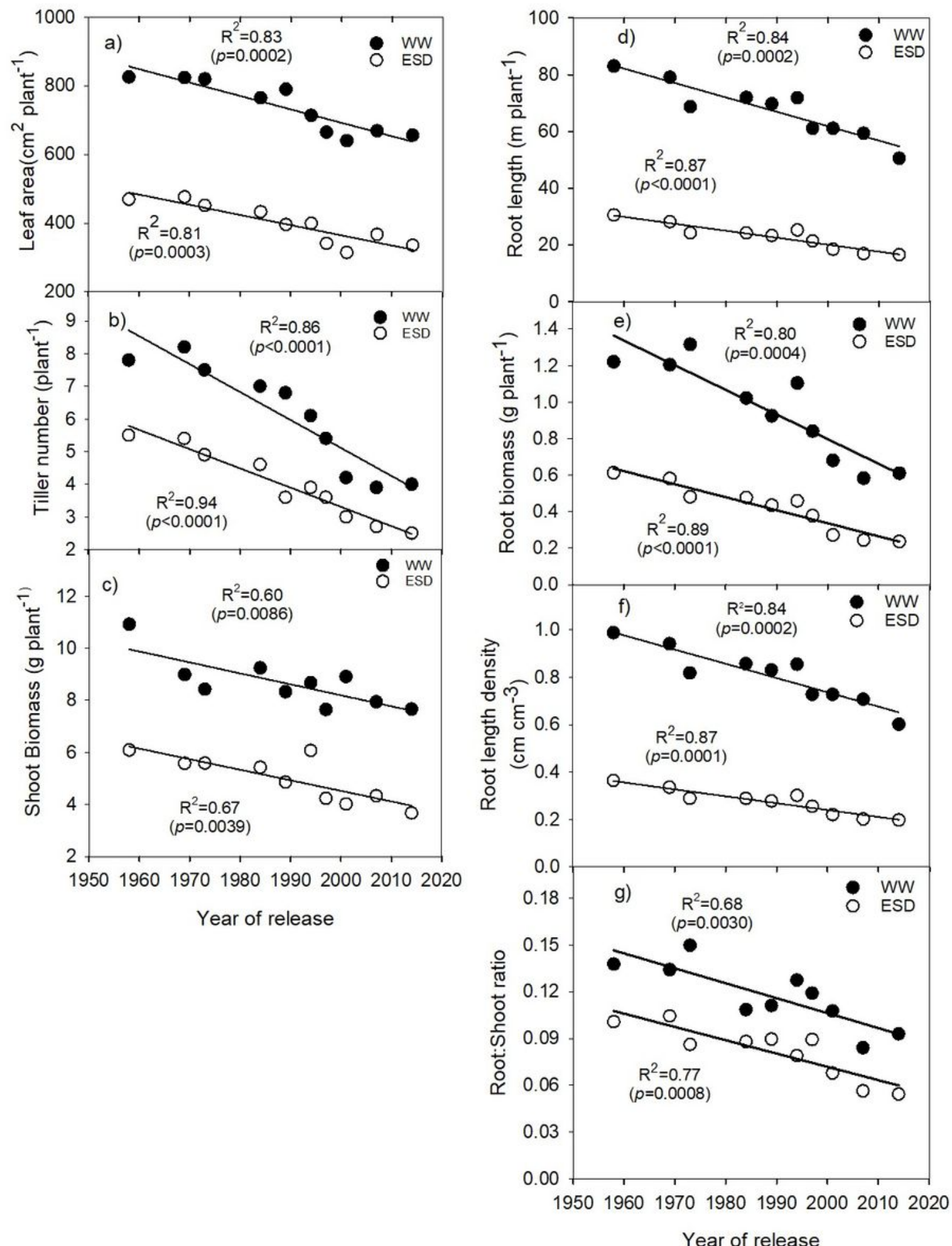

\section{Figure 3}

Shoot and root traits at anthesis of Australian wheat varieties released from 1958 to2012 grown in $1 \mathrm{~m}$ deep PVC columns under early-season drought (ESD) and well-watered (WW) conditions. Measurements were made at $50 \%$ anthesis of each variety (Z61). Values are the mean of four replicate columns(two plants per column)per variety per year of release 


\section{Figure 4}

Time to $50 \%$ anthesis (Z61) and physiological maturity (Z91) and grain filling duration of Australian wheat varieties released from 1958 to2012 grown in 1 m deep PVC columns under earlyseason drought (ESD) and well-watered (WW)conditions. Values are the mean of four replicate columns (two plants per column) per variety per year of release. 
Year of release
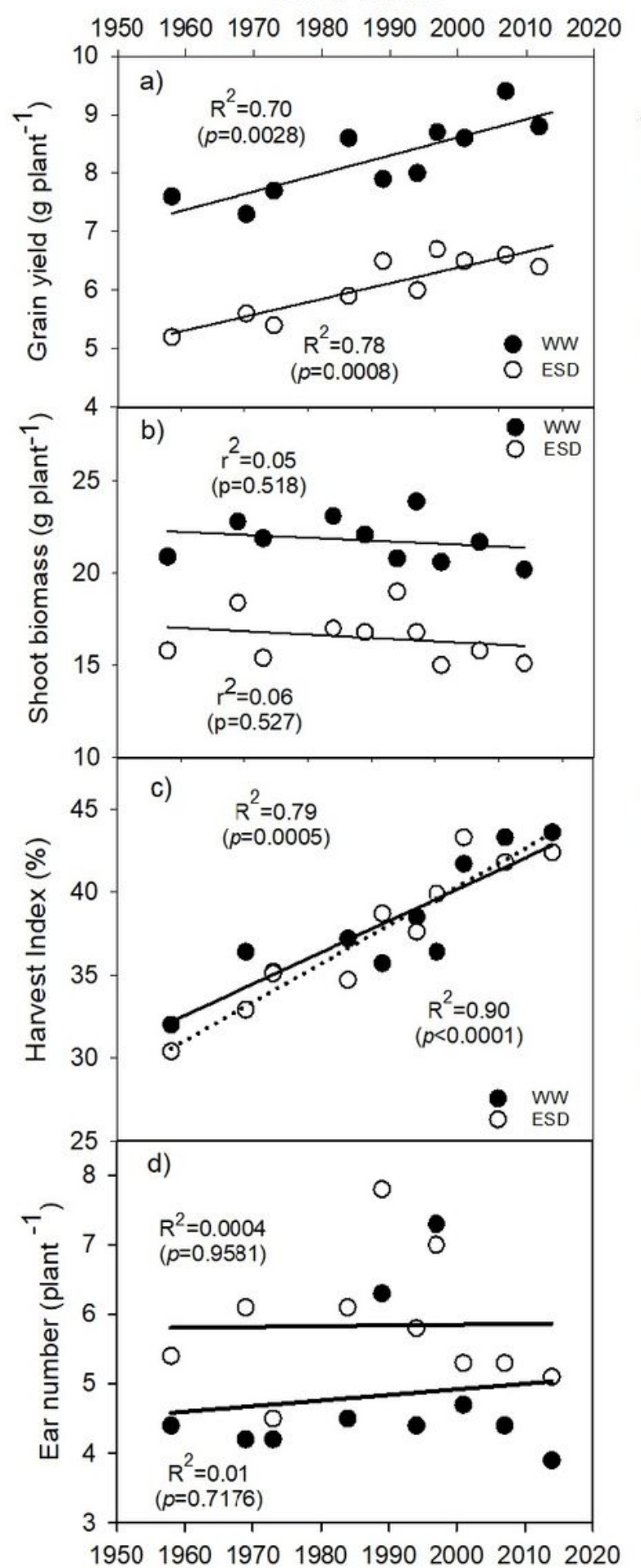

Year of release
Year of release

19501960197019801990200020102020

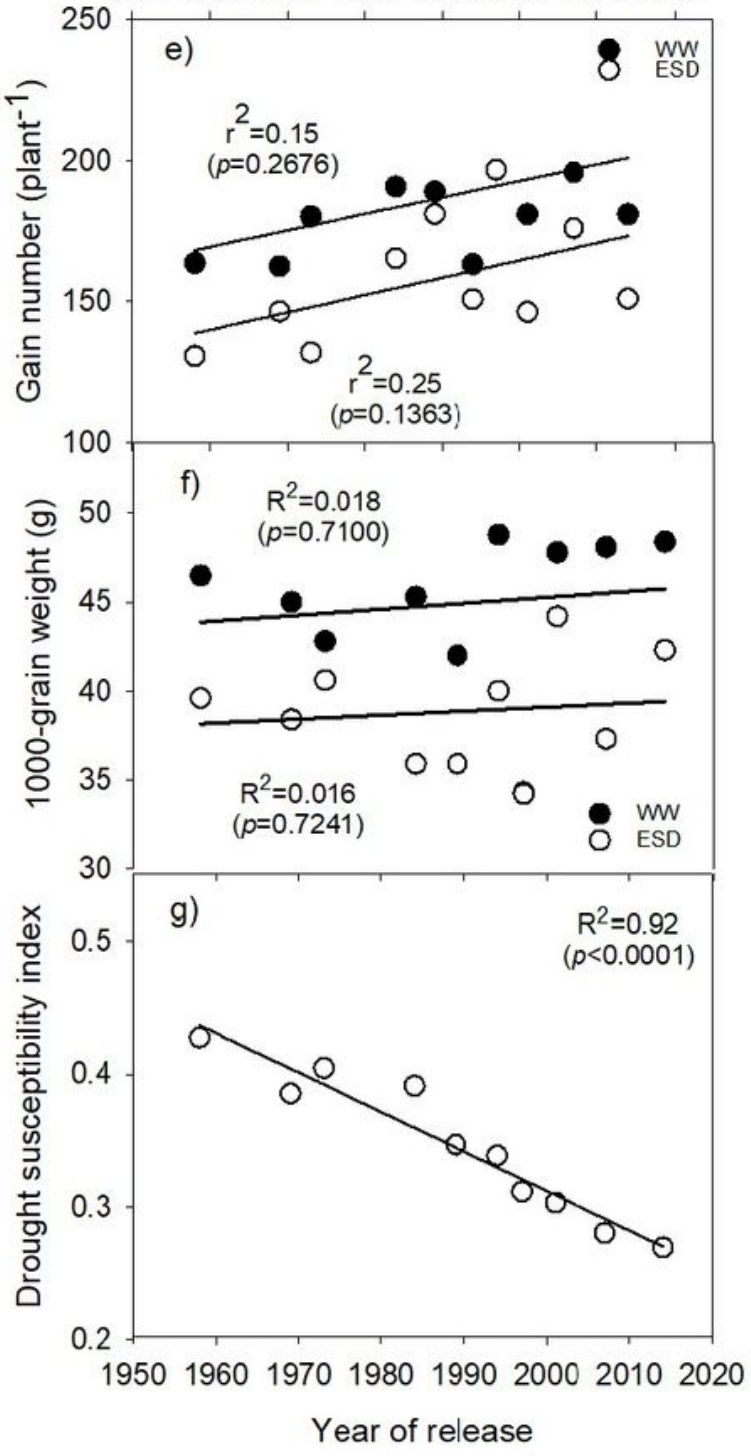

\section{Figure 5}

Yield, grain yield components and drought susceptibility index (SDI) of Australian wheat varieties released from 1958 to2012 grown in 1 m deep PVC columns under early-season drought (ESD) and wellwatered (WW)conditions. Values are the mean of four replicate columns (two plants per column) per variety per year of release. 